\title{
ARTICLES
}

Submitted 02.18.2014. Approved 05.28.2014

Evaluated by double blind review process. Scientific Editor: Martin Jayo

http://dx.doi.org/10.1590/S0034-759020150502

\section{IMPLEMENTATION OF GREEN IT IN ORGANIZATIONS: A STRUCTURATIONAL VIEW}

\author{
Implementação da TI Verde nas organizações: uma visão estruturacional \\ Implementación de TI Verde en las organizaciones: una visión estructuracional
}

\section{DÉCIO BITTENCOURT DOLCI}

dbdolci@gmail.com

Professor at Universidade Federal

do Rio Grande, Instituto de Ciências

Econômicas, Administrativas e

Contábeis - Rio Grande - RS, Brazil

\section{GUILHERME LERCH LUNARDI}

gllunardi@furg.br

Professor at Universidade Federal do Rio Grande, Instituto de Ciências Econômicas, Administrativas e

Contábeis - Rio Grande - RS, Brazil

\section{ANA CAROLINA SALLES}

salles.ac@bol.com.br

Master's candidate in Business

Administration from the

Universidade Federal do Rio Grande

do Sul, Programa de Pós-Graduação

em Administração - Porto Alegre -

RS, Brazil

\section{ANA PAULA FERREIRA ALVES \\ anapfalves@gmail.com \\ Ph.D. Candidate in Business \\ Administration from the \\ Universidade Federal do Rio Grande \\ do Sul, Programa de Pós-Graduação em Administração - Porto Alegre - RS, Brazil}

\begin{abstract}
Environmental sustainability has become increasingly important to businesses as a response to the rapid depletion of natural resources. Information Technology (IT) in particular represents a meaningful part of the environmental issues that society has been facing. Therefore, Green IT emerges as a way of combining available resources and sustainable and economic policies, thus, generating benefits for both the environment and businesses. The purpose of this paper, hence, is to explain the dynamics of Green IT implementation in organizations in light of the structurationist view of technology. We conducted a case study research based on the cases of three Brazilian companies interested in this movement. Results provide a better understanding of the relationship among technology, individuals, and organization institutional properties, thus enhancing the role played by IT teams in institutionalizing the environmental dimension of sustainability in organizations.
\end{abstract}

KEYWORDS | Green IT, structurational view, implementation, Green IT practices, IT team.

\section{RESUMO}

A sustentabilidade ambiental tem se tornado muito importante para os negócios como resposta à rápida degradação de recursos naturais. A Tecnologia da Informação (TI), mais especificamente, tem sido responsável por parte dos problemas ambientais que a sociedade enfrenta ultimamente. Neste sentido, a TI Verde aparece como uma forma de combinar recursos disponíveis a políticas de sustentabilidade e economia, gerando benefícios para o ambiente e para os negócios. Assim, objetiva-se neste artigo explicar a dinâmica da implementação da TI Verde nas organizações sob a perspectiva estruturacionista da tecnologia, por meio de um estudo de múltiplos casos realizado com três empresas brasileiras interessadas neste movimento. Os resultados permitem uma melhor compreensão da inter-relação entre a tecnologia, os indivíduos e as propriedades institucionais da organização, destacando o papel da equipe de TI na institucionalização da dimensão ambiental da sustentabilidade nas organizações.

PALAVRAS-CHAVE I TI Verde, visão estruturacional, implementação, práticas de TI Verde, equipe de TI.

\section{RESUMEN}

La sustentabilidad ambiental se ha vuelto de vital importancia para los negocios como respuesta a la disminución rápida de los recursos naturales. La Tecnologías de la Información (TI) en particular representa una parte significativa de los problemas ambientales que ha enfrentado la sociedad. Por lo tanto, la TI Verde surge como una forma de combinar recursos disponibles y políticas sustentables y económicas, y por lo tanto, generar beneficios para el medio ambiente y los negocios. El objetivo de este artículo, por lo tanto, es explicar la dinámica de la implementación de TI Verde en organizaciones, a la luz de la visión estructuracionalista de la tecnología. Llevamos a cabo una investigación de estudio de caso en los casos de tres empresas brasileñas interesadas en este movimiento. Los resultados ofrecen un mejor entendimiento de la relación entre tecnología, individuos y propiedades institucionales de la organización y, por lo tanto, mejorar el rol representado por los equipos de TI en institucionalizar la dimensión ambiental de sustentabilidad en las organizaciones.

PALABRAS CLAVE I TI Verde, visión estructuracional, implementación, prácticas de TI Verde, equipo de TI. 


\section{INTRODUCTION}

Issues related to sustainability have become increasingly important to business scholars and practitioners in the last decades, as a result of both natural resource depletion and wealth disparity (Dao, Langella, \& Carbo, 2011). Such issues have recently spread to the domain of Information Technology (IT), the impacts of which on natural environment can be classified in two categories: firstorder effects, i.e., when technology represents a significant and increasingly larger part of the current environmental problems faced by society (thus concerning the negative environmental impact of IT production, use, and disposal); and second-order effects, i.e., when technology provides important solutions to mitigate these problems (thus concerning the positive impact of using IT on businesses and economic processes) (Molla \& Abareshi, 2012). In this context, the concept of Green IT or Green Computing stands out as a socio-technical movement which implements policies, practices, strategies, and IT products (software and hardware) that can help improve and foster environmental sustainability (Salles, Alves, Dolci, \& Lunardi, 2013).

Given the increasing demand by regulatory agencies, consumers, and society for better environmental management, several organizations have been dedicating time and resources to protecting the environment and implementing different strategies to mitigate the impact of their IT operations, so that energy consumption and waste generation can be decreased (Ko, Clark, \& Ko, 2011). Jenkin, Webster, and McShane (2011) examined the relationship among four components (motivating forces, environmental sustainability initiatives, environmental orientation, and environmental impacts) and developed a multilevel research framework for environmentally sustainable IT/IS research, suggesting several theoretical propositions that could help overcome challenges associated with implementing Green IT. By focusing on the central part of this framework, we conducted a case study research based on the cases of three Brazilian companies interested in the Green IT movement. The resulting paper describes the dynamics of the interaction among technological systems, institutional properties, human choices, and actions that reinforce an environmental orientation over time. In this perspective, we can see that the actions of individuals in organizations are guided by a social construction process that occurs in time and space and constitutes a set of practices that depend on several factors, such as the specific way in which every organizational actor learns his/her roles and relates to other people.

Nowadays, individuals use IT to execute a large part of their activities, both inside and outside the organizations where they work. With regard to environmental sustainability, the choice for certain technologies has been addressed by several studies
(Lunardi, Alves, \& Salles, 2012; Murugesan, 2008; Zhang \& Liang, 2012). However, it is necessary to understand better how this behavioral change phenomenon occurs in an organizational environment. Therefore, this paper aims to explain the dynamics of Green IT metastructuration and structuration processes in organizations in order to help perceiving the establishment of environmental sustainability as an institutional property of an organization. This reflection was based on empirical data collected in companies interested in Green IT practices, in light of the structurationist view of technology, particularly based on Orlikowski's studies, that have been recognized as relevant not only in research of Information Systems (IS) but also in Organization studies (Pozzebon, Diniz, \& Jayo, 2009).

Through this lens, we attempt to understand the introduction of Green IT practices into organizations, by examining actions, conditions and consequences in different groups and levels presented in the organizational context. According to Giddens, practices are those social actions that recursively produce and reproduce the structures that constrain and enable actions (Feldman \& Orlikowski, 2011). The present study considers the two research orientations that have been used in structurationist studies of technology: one focused on technology and its impact on use (Orlikowski, 1992) and one focused on human agency and on enacting emergent structures in the recurrent use of technologies (Orlikowski, 2000). The latter is most indicated to explore what Orlikowski (2000) termed technologies-in-practice. Feldman and Orlikowski (2011) enhance the distinction between technological artifacts and technologies-in-practice, a distinction that offers some practical insights as to how technology can be introduced and managed in organizations. In addition to being an attempt to contribute on that issue, the present study is relevant to verify the application of previous theoretical models in new contexts such as Green IT.

It is worth noting that this reflection does not intend to exhaust this complex subject; on the contrary, it aims to trigger further discussion about Green IT in light of Giddens's Theory of Structuration, one of the most widely used social theories in IS studies (Jones \& Karsten, 2008). Although Giddens' view may sometimes by overly theoretical - and he has not dealt with technology in his theory - Orlikowski and her academic peers have provided models and frameworks that can help investigate IT using Giddens's social theory.

\section{LITERATURE REVIEW}

The literature review carried out in this research was based on two pillars: Sustainability and Giddens's Theory of Structuration. 
The former approaches the environmental dimension of sustainability and its relation to Green IT. The latter examines the metastructuration and structuration processes of technology in organizations and the establishment of institutional properties.

\section{Green IT in the context of sustainability}

The significant scientific and technological development that has taken place over the last decades has ignored the connection between Economics and Ecology, bringing as its main negative outcome the planet's rapid resource depletion. Impacts, mainly resulting from industrial demands, population growth, and increase in social inequity have led to environmental, social, and economic problems directly affecting the scarcity of non-renewable resources, the increase in per capita waste generation, and the lack of residue storage areas, all of which clearly point to unsustainable development, one that is socially unfair, environmentally unbalanced, and economically unviable (Claro, Claro, \& Amâncio, 2008). In this context, which intertwines environmental concerns and socio-economic issues, the UN World Commission on Environment and Development, in its report "Our Common Future" (also known as Brundtland Report), conceptualized the term "sustainable development" as the development that meets the needs of the present without compromising the ability of future generations to meet their own needs (World Commission on Environment and Development [WCED], 1987).

Due to its broad and vague features, this definition resulted in an array of lines, concepts, and conceptions about the theme (Claro et al., 2008) which contributed to its widespread status around the world. One of the most common interpretations of sustainability is the triple bottom line (TBL) concept, which states that sustainable development must comprise the social, environmental, and economic dimensions (Elkington, 2001). When applied to the organizational area, TBL aims to analyze sustainability beyond the traditional measurements of profit, return on investment, and value generation for shareholders, in order to include social and environmental issues (Elkington, 2001; Slaper \& Hall, 2011). From this perspective, the beginning of a new paradigm in business management is expected, driven by sustainability, integrated economy, environment, and society, through greater sustainability awareness (Barata et al., 2014).

Companies have been led to admit the seriousness of their socio-environmental impacts and to carry out voluntary and continuous actions to mitigate them. Regarding the environmental dimension, the number of organizations that include environmental practices in their strategies and daily operations has grown. These companies aim at reducing energy consumption, carbon footprint emissions, the amount of non- renewable resources they use, and the quantity of residues they generate (Ozturk et al., 2011). In the IT area, these environmental problems are more visible than those found in other areas. However, the so-called IT-for-green approach considers IT the potential solution to environmental problems, rather than its cause (Dedrick, 2010). Therefore, the adoption of Green IT practices has involved a new perspective to operations, the positive results of which can improve organizations' both economic and environmental development while disrupting the idea of a conflict between Economics and Ecology.

The effect of IT on the environmental dimension of sustainability and the magnitude of the theme sustainability have triggered scholars' interest in researching Green IT (Jenkin et al., 2011; Melville, 2010; Sisaye \& Birnberg, 2010; Watson, Boudreau, \& Chen, 2010). However, Green IT is neither a thoroughly defined concept nor a set of commonly accepted practices (Lunardi, Frio, \& Brum, 2011). According to Murugesan (2008), Green IT is the study and practice related to designing, manufacturing, using, and disposing of computers, servers, and associated subsystems (monitors, printers, storage devices, and network and communication systems) efficiently and effectively, with minimal or no impact on the environment. In addition, it is concerned with waste, energetic efficiency, and total ownership cost, which includes discharge and recycling costs. Schmidt, Erek, Kolbe, and Zarnekow (2010) have added that Green IT also comprises tools to control, guide, and communicate the practices adopted. The authors took into account the complete life cycle of information and communication technologies, involving environmentally correct design, production, operation, and elimination processes (Elliot, 2007).

In this perspective, Green IT can be understood to consist of: a holistic and systematic approach to facing challenges related to IT infrastructure; IT's contribution to reducing the environmental impact of companies' IT operations; IT's support for environmentally sustainable business practices carried out in companies; and IT's role in the low-carbon economy (Molla et al., 2008). In a socio-technical view, Brooks, Wang, and Sarker (2010) divided Green IT in: (a) initiatives that use IT infrastructure to change organizational processes and/or practices to improve energy efficiency and reduce environmental impacts; and (b) the introduction of environmentally healthier IT products and/or services. Thus, Green IT can introduce not only environmentally favorable strategies in organizations but also environmentally correct products in the market. It is worth highlighting that the pursuit of sustainability does not mean that economic thinking must be abandoned; in fact, economics addresses the problem of allocating scarce resources, such as emission-free energy and electro-electronic components, which are particularly scarce resources (Watson et al., 2010). 
According to Bose and Xin (2012), several studies show that the IT area has been critical in facing problems, but the need remains to involve the whole organization in order to achieve significant results. They also pointed that IT's negative impact on the environment can be mitigated through technological and behavioral changes. The former should focus on improving IT and business infrastructures in order to make them environmentfriendly. In this respect, adequate, conscious choices of products and services in IT and other activities in the organization - towards greater energy efficiency and better use of the resources involved in IT infrastructure use and development - have contributed to reduce environmental impact. Behavioral changes, in turn, can be achieved by acting in an environmentally responsible manner and by developing and enforcing organizational policies and initiatives in line with the "green" IT strategy undertaken by the organization.

Jenkin et al. (2011) have developed a conceptual research framework (Figure 1) that proposes a comprehensive look at Green IT/IS issues in terms of corporate environmental initiatives and their environmental impacts. Their theoretical propositions have addressed several challenges and gaps at both individual and organizational levels of Green IT analysis. The study reported in this paper focuses exclusively on the dashed area in Figure 1 and analyzes the recursiveness between environmental initiatives and guidelines. The analysis uses features of Giddens's Structuration Theory. According to Giddens (1984), structure and agency are mutually constitutive; society is a complex system of recurrent practices that constitute social institutions and individual identity. An important variation of Giddens's work, primarily for studying IS phenomena, is the work developed by Orlikowski (1992, 2000) and Orlikowski, Yates, Okamura, and Fujimoto (1995). Based on Giddens' Structuration Theory, they have studied the duality of technology, i.e., technology as a social product of human action in a specific cultural and structural context, and technology's constitutive role in which a set of rules and resources contributes to mediate (by facilitating or constraining) the human action; thus, technology helps create, recreate, and transform these contexts, and therein lies one of the premises of the structurationist view of technology. In order to extend previous studies of this issue, Pozzebon et al. (2009) proposed a framework considering studies of complex and multilevel interactions (at individual, group, organization, regional, or societal levels).

Figure 1. Multilevel framework for environmentally sustainable IT/S research

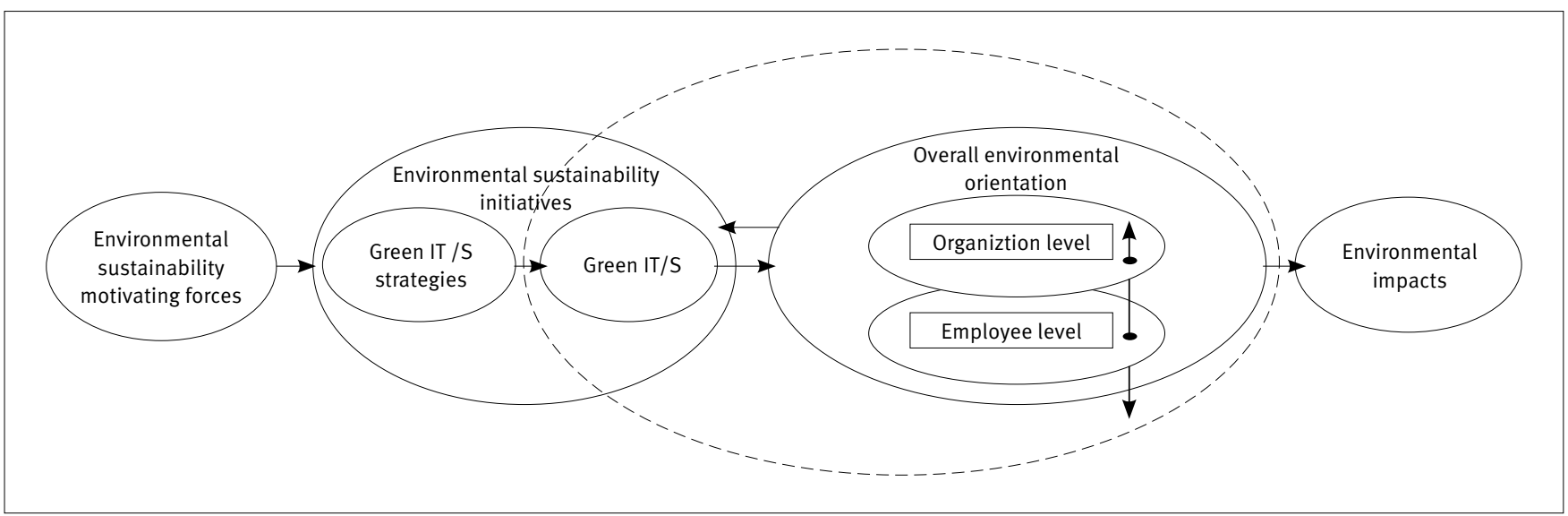

Source: Adapted from Jenkin et al. (2011, p. 21)

\section{Structuring and metastructuring processes of technology in use}

Most studies of structuration in IS research have adopted Giddens's Structuration Theory standpoint (Figure 2) (Jones $\&$ Karsten, 2008). Since many practices have developed from everyday work, this theory helps us understand how the structuration process of human action occurs, as it broadens the perception of rules and resources inherent to social systems that belong to a certain social structure. Giddens (1984) argues that the duality of structure concept consists in rules and resources implicit to the production and reproduction of the environment; they are, at the same time, the reproductive means of the system. According to Giddens, structure is simultaneously restrictive and facilitative; this process presupposes reflexive monitoring and the integration of agents into social activities with limited actions and consequences.

Giddens also specifies three modalities - interpretive schemes, facilities, and norms - that link the realm of action (interaction) and the realm of social structure (structure). Actors draw on the modalities of structuration to reproduce interaction systems, and reconstitute the systems' structural properties 
by the same token. Interpretive schemes are actors' stocks of knowledge applied reflexively in the sustaining of communication. The stocks of knowledge that actors draw on to produce and reproduce interaction are the same ones whereby they are able to offer accounts, reasons, etc. Facilities are the means through which actors realize their intentions, achieve their goals, and exercise their power. Norms are the rules that shape the conduct and define the legitimacy of interaction.

\section{Figure 2. Giddens's structuration model}

\begin{tabular}{|c|c|c|c|}
\hline \multirow[t]{2}{*}{ structure } & signification & domination & legitimation \\
\hline & $\mathbf{A}$ & 4 & $\mathbf{A}$ \\
\hline \multirow{3}{*}{ modality } & $\nabla$ & $\mathbf{v}$ & $\nabla$ \\
\hline & interpretative & facility & norm \\
\hline & 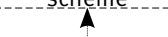 & $\mathbf{A}^{---}$ & $\Lambda^{--}$ \\
\hline & $\nabla$ & $\nabla$ & $\nabla$ \\
\hline interaction & communication & power & sanction \\
\hline
\end{tabular}

Source: Giddens (1984)

It is worth mentioning that Giddens does not clarify how technology is introduced in this process of social changes; this became a major theme in Orlikowski's studies (Orlikowski, 1992, 2000; Orlikowski \& Gash, 1994; Orlikowski \& Robey, 1991; Orlikowski et al., 1995). Based on Giddens's Theory of Structuration, Orlikowski (1992) proposed a structurational model of technology which reconceptualizes the nature of technology in organization research. Her first studies apply a view that starts with structures presumed to be embedded within technology (Orlikowski, 1992; Orlikowski \& Gash, 1994; Orlikowski \& Robey, 1991). Some years later, based on further fieldwork and colleagues' constructive criticism, she modified her structurational view of technology by actively theorizing the relationship between everyday practices and technologies in use (Feldman \& Orlikowski, 2011). Her revised view stresses that technology as artifact does not embody structures because these can only be instantiated in practice. Technology structures are not external to, or independent of, human agency, nor can they be embodied in technologies.

In this sense, "it is thus not technologies per se, nor how they may be used in general that matter, but the specific technologies in practice (enacted technology structures) that are recurrently produced in everyday action that are consequential for the shaping of organizational outcomes" (Feldman \& Orlikowski, 2011, p. 1247). According to Orlikowski (2000, p. 407), "these enacted structures of technology use", which she terms technologies-in-practice "are the sets of rules and resources that are (re)constituted in people's recurrent engagement with the technology at hand". By considering technology-in-practice (rules and resources instantiated in the use of technology) as a kind of structure, Orlikowski (2000) adopts the modalities of structuration (Giddens, 1984) in order to illustrate that hardware and software are examples of facilities; protocols and etiquette are examples of norms; and assumptions and knowledge are examples of interpretive schemes.

In the meantime, Orlikowski et al. (1995), based on the structurational model of technology, propose two new dimensions to its analysis: mediation and technology in use (Figure 3). The authors define mediation as a deliberate, ongoing, and organizationally-sanctioned intervention within the context of use that helps to adapt a new technology to that context, modifies the context as appropriate to accommodate the use of that technology, and facilitates its ongoing effectiveness over time. By including the mediation and technology in use dimensions, Orlikowski and her co-workers highlight the metastructuration process that occurs in the introduction phase of a new technology, i.e., the interaction among the technologies the organization already uses and the mediation carried out by IT managers/professionals in the structuration process of a newly adopted technology. The term “metastructuration" refers to an organizational mechanism aimed at continuous adaptation of technologies, their use, and their organizational contexts, so that favorable conditions for change can be achieved (Orlikowski et al., 1995). The framework shows both the metastructuration process of technology in use and its structuration process. With regard to the use of technology and its mediation, several interdependencies can be perceived among the following elements: institutional properties, technology, and human actions.

The theoretical framework developed by Orlikowski et al. (1995) is the most suitable to this investigation. Although it does not emphasize technologies-in-practice (Orlikowski, 2000), it aids to develop a better explanation about the dynamic inscribed in the processes. By exposing conditions and consequences arrows - it makes it easier for us to understand the relations and co-evolution of the following three elements: technology, work organization (Green IT adoption and use), and institutional properties of an organization.

Sustainability may have become an institutional property in organizations; thus, IT initiatives using Green IT practices create a spiral that reinforces environmentally sustainableoriented guidance. This spiral presupposes the influence of IT at a community/societal level; Pozzebon et al. (2009) reinforce that technology content alone will not influence the process and outcomes of technologies-in-practice and emergent social structures. IT implementation and use can be understood as a process of negotiation where the identification of occasions, spaces, and mechanisms allowing negotiation and change seems crucial. According the structurationist, multilevel framework 
(Pozzebon et al., 2009), the context influences the process, which in turn influences the content, which influences the context, and so on. Although this dynamic seems quite similar to the model presented in Orlikowski et al. (1995), some attention is required, as the former presupposes the presence of relations of influence between the elements, while the latter presents relationships of conditions and consequences.

\section{Figure 3. The technology metastructuration and structuration processes}

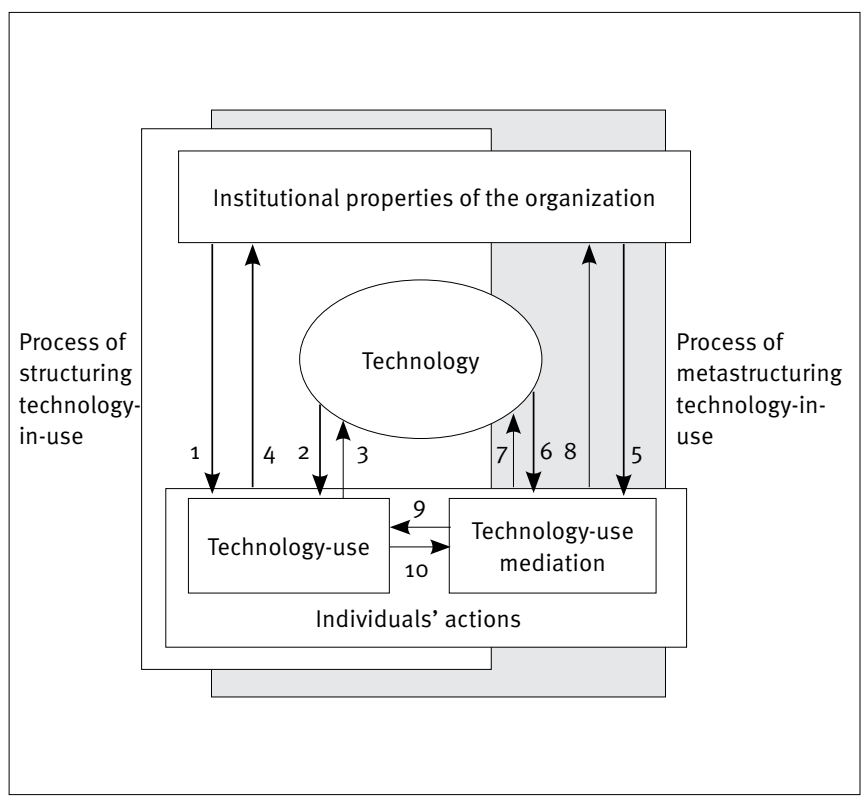

Arrow 1 - Institutional conditions for use

Arrow 2 - Technological conditions for use

Arrow 3 - Technological consequences of use

Arrow 4 - Institutional consequences of use

Arrow 5 - Institutional conditions for mediation

Arrow 6 - Technological conditions for mediation

Arrow 7 - Technological consequences of mediation

Arrow 8 - Institutional consequences of mediation

Arrow 9 - User consequences of mediation

Arrow 10 - User conditions for mediation

Source: Orlikowski et al. (1995)

\section{METHOD}

Firstly, a theoretical analysis was carried out with the help of a bibliographic review in order to comprehend and report how sustainability has been defined and understood in both its environmental dimension and its relation to IT. Likewise, Giddens's Theory (1984) was studied in combination with the metastructuration and structuration model proposed by Orlikowski et al. (1995). Afterwards, a "multi-case explanatory study" (Yin, 2001) was carried out. This methodology allows using several evidence sources to solve research problems related to "how" and "why" (Yin, 2001).
Our analysis was conducted at an organizational level as it focuses on aspects found in every company selected for this study. We view it as a qualitative research aimed at interpreting a certain reality found, rather than generalizing it. The study was conducted with three Brazilian companies in the state of Rio Grande do Sul, Brazil. They were chosen because of their representativeness in their economic sectors, as well as the fact that they have been committed to developing sustainable initiatives in their IT departments.

Data were collected using interviews with semi-structured guidelines, mainly comprised of open-ended questions. In addition, a structured questionnaire with closed-ended questions was applied. Secondary methods of data collection were also used. The instruments were based on questions that emerged after the theoretical review on sustainability and Green IT was conducted. Once the questions were written and the research instruments organized, we proceeded to interview IT managers at the investigated companies and apply the structured questionnaires with IT users. The semistructured guidelines contained questions about company and interviewee characteristics, and 11 other questions on factors that triggered sustainable actions in the IT department, the relation between Green IT and the company's strategies, practices adopted, critical success factors, and perceived benefits and challenges. The structured questionnaire evaluated users' perception of Green IT's presence in the organization, identifying different components affecting the way organizations have addressed environmental sustainability in the IT area. Secondary methods of data collection included observing the companies' environment in order to identify the various (green) computing equipment and sustainable practices implemented. We also checked the firms' websites and documents in order to complement information collected in the interviews and visits to the facilities (to check information given by the managers in their interviews).

All companies under investigation were implementing some improvement program based on the adoption of Green IT practices. Company $1\left(\mathrm{C}_{1}\right)$ is a medium-sized company in the pharmaceutical retail industry which directly employs 87 workers in 8 branches. This company is part of a pharmaceutical retail chain that uses a cooperation system to increase competitiveness against large market players. It tries to use its bargaining power with suppliers in order to offer consumers competitive prices. Company 2 ( $\left.\mathrm{C}_{2}\right)$ is a large-sized company in the fuel retail industry which directly and indirectly employs about 450 workers in nineteen gas stations across the state. Also large-sized, Company $3\left(C_{3}\right)$ is a container terminal in the port logistics industry, in the import-export sector. This company employs about 1,000 direct 
workers, with a pyramid structure where decisions are centralized in the management and passed down across the organization.

To initiate the data collection process, we first sent an e-mail to the companies explaining the research theme and goals and inviting them to participate. Once we had their formal acceptance, we proceeded to interview the CIOs at their offices for about one hour. In addition, we applied the structured questionnaire with three IT users at each company. Data were analyzed according to their compatibility with the theoretical dimensions of the model of Orlikowski et al. (1995), which allowed us to found both the analysis and the results (next item).

\section{RESULTS}

The dynamics of the institutionalization of Green IT in the organizations investigated are explained in light of the model proposed by Orlikowski et al. (1995). Facts are identified by the abbreviations $\mathrm{c}_{1}, \mathrm{c}_{2}$ and $\mathrm{c}_{3}$ - the number identifies the company as described in the previous section (methodology). They reveal different, important types of conditions and consequences presented in the dynamics of the Green IT structuration process in the studied firms, with implications beyond IT borders.

According to Orlikowski (2000), different types of conditions can be found: interpretive, technological, and institutional. Interpretive conditions refer to approved agreements and shared meanings that members of a community use to make sense of their world (such as the technology they use). Technological conditions refer to technological properties (both tools and data) available to users in their work practices. Finally, institutional conditions refer to the social structures (normative and authority-related) that constitute part of the broad social system in which users work. As to the consequences (intended or unintended), the most relevant are the processual, technological, and structural ones. The processual ones refer to changes in the execution and results of work practices, technological ones refer to changes in the technological properties available to users, and the structural ones refer to changes in structures that users establish as part of the broad social system they participate in.

The right side of Figure 4 shows the metastructuration process occurring when a new Green IT is brought forward. The left side presents the structuration process resulting of users' continuous use of technology. As to the influence of technologyin-use on its mediation, it is represented by two arrows: arrow $10 a$ indicates conditions for mediation and arrow 10b shows the consequences of the use of technology on mediation; the latter emphasizes user feedback to mediators (IT team).
Figure 4. Structuration process of the environmental sustainability property in Green IT

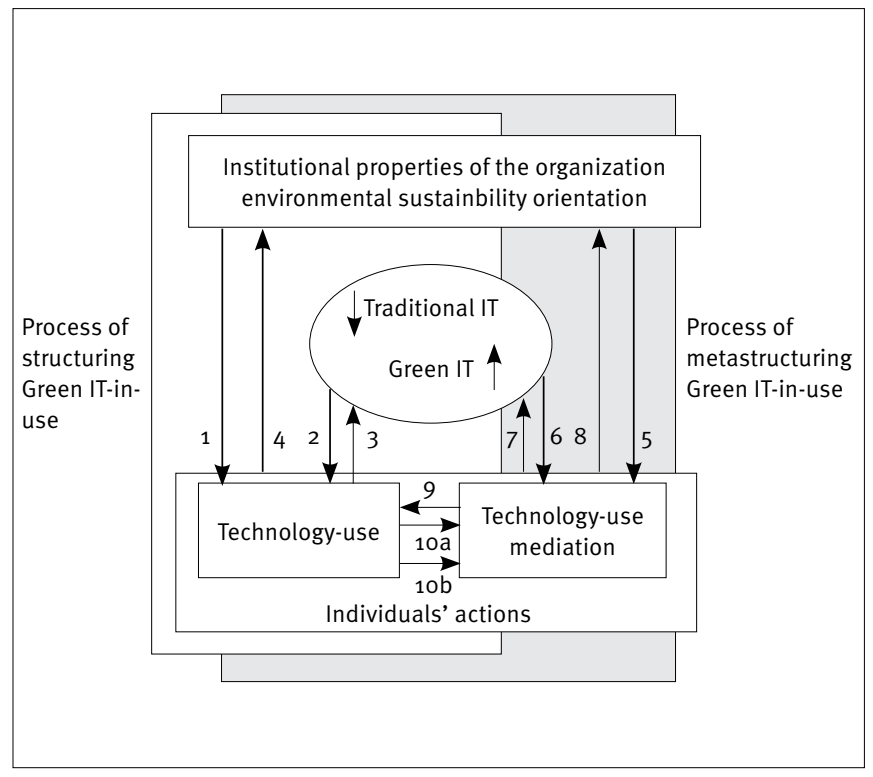

\section{Conditions determining the change to Green IT}

On the right side, with regard to technology mediation, IT managers are pressed by the organization's institutional properties to take more sustainable decisions (arrow 5). These properties can be explained by the institutional context, i.e., governmental regulations applying to the company's commercial activity, such as electronic invoicing (c2, c3) and legal environmental procedures to start and run the business (c2). Moreover, there are internal pressures for results, such as more efficiency in the processes, careful material spending, less depreciation and maintenance (c1), and external pressures from suppliers (c2). Finally, the company itself aims to become more sustainable and committed to managing environmental liabilities and organization image $\left(c 2, c_{3}\right)$. By then, the IT team is able to invest time and resources to adopt different Green IT initiatives. The organization itself has a certain level of environmental orientation and social commitment that value these environment-focused technologies and organizational routines (Jenkin et al., 2011).

It is worth mentioning that an orientation towards Green IT differs from the adoption of just any IT, mainly because of the importance that issues related to ethics and environmental sustainability have in the decision-making processes. The adoption of any IT is usually motivated by potential economic benefits achieved by this technology whereas Green IT practices are also prompted by concerns for the planet, even though economic benefits may not be tangible in the short term. Organizations that care about their social and environmental responsibility, 
business sustainability, and Green IT have dealt with these issues by carrying out clear policies on equipment acquisition (less energy consumption, recycled material, and non-polluting material), the use of computers and printers (more efficient computational processes, cartridge refilling, paper recycling, and less printing) and computers and datacenter facilities design (virtualized, smaller facilities, with less energy consumption and better air conditioning systems) (Lunardi et al., 2011).

In this process of change, conditions imposed by users when using conventional technologies (arrow 10a) and by current technologies themselves (arrow 6) must also be taken into account. In this respect, we have found that IT users did not oppose to sustainable initiatives in the metastructuration phase. Apparently, the IT team has a certain level of autonomy and confidence to implement these changes. At this stage, users' passive or active resistance may not be perceived due to a predominant indifference (Giangreco, 2002). Expressions of both passive and active resistance may appear later, when users actually use Green IT. Conditions imposed by companies' current technologies have guided IT teams as to possible designs and the replacement of current technologies.

\section{Potential Green IT artifacts and their technological consequences}

Even though an organization may adopt different "green" practices, it will still be using existing technologies. The replacement process and the adoption of "new" technologies mean that they will both qualify and constrain them. Based on IT-offered resources (arrow 6), the IT area, relying on Green IT assumptions, starts to test and introduce designs made possible by computational artifacts - equipment, operational systems, and applications - while investing in proposals that are more adequate to Green IT (arrow 7), such as servers consolidation and virtualization ( $\left.1, c_{2}, c_{3}\right)$, the introduction of thin clients (c2), and printer usage monitoring (c1, c2, c3). It is worth highlighting that such initiatives also constrain (arrow 6) the way mediators work and, later, the way users apply this technology, such as assigning print quotas to individual users (c1, c2) and controlling the use and access to software and information (c2).

These technological novelties have been identified by the IT area in the media (in the news or in new product launches) (c1, c3), in reported cases of companies that saved energy and money by using cleaner computational technologies (c1, c2), and even by hiring companies specializing in the area (c2). Such IT department-started initiatives may at first lead to technological consequences; these, however, are the least relevant in the present study. The consequences that interest us which arise in this process of technology metastructuration are discussed below.

\section{Other consequences of Green IT mediation}

The more Green IT practices are adopted by the IT team, the more they influence the technology applied by users. However, the constant use of these initiatives by the IT department reinforces the organization's “green” institutional properties (arrow 8). Some examples of actions that were first implemented by the IT department are the use of teleworking and teleconferencing (c2), email messages rather than printed copy format (c1, c3), high efficiency equipment (c1, c2, c3), corporate messenger applications, and printing using eco-font (c1). A fact common to all three cases was the replacement of CRT monitors by LCD ones (c1, c2, c3) as the latter need less space and energy. This set of practices - when it occurs in the metastructuration phase - influences the organization's institutional properties, not only leading it to more sustainable values but also causing it to commit to the environment and society. These cases show initiatives that reinforce the organizations' reduction of operational costs in line with concerns such as global warming.

By learning more about Green IT and the use of equipment and services that support environmentally sustainable strategies, the IT team starts to influence others in the organization in terms of both implicit and explicit knowledge (arrow 9). This can be seen in practices related with awareness raising campaigns and training programs (c1, c2) and energy efficiency analysis (c1, c3) within the organization. Users learn to identify costs and risks of business activities and are encouraged to participate in "green" technology development and implementation processes.

The organization can occasionally resort to different alternatives in order to encourage individual and collective development, i.e., working on environmental education (c3), which promotes understanding about the adoption of Green IT practices. Assimilation depends largely on employees' attitudes, cognition, and behavior, as well as on the organization itself according to the importance they attribute to environmental issues (Jenkin et al., 2011) and their belief that these initiatives can actually help the environment. The dissemination of Green IT practices awakens ecological awareness in the company (c1, c3), although the challenge remains to find ways of mobilizing people towards changing their behavior. Moreover, the process may take a long time. Still, there is evidence that the younger generations have already incorporated environmental issues into their education processes (c3), making assimilation and dissemination easier. 


\section{Using Green IT: technological conditions and early consequences}

The mediation conducted to clarify these technological process changes has been accompanied by constraints and advantages proposed with the new technological configuration. The interaction among individuals leads to deeper communication among users and the IT team. Green IT-in-use becomes part of the organizational environment, which is constantly updated and, in turn, suggests changes/updating in the new contexts. Issues previously restricted to the IT team - eco-fonts, LCD monitors, more efficient machines, screen savers, printing quotas - become potential organization-wide technologiesin-use (arrow 2). However, users' participation must be emphasized since they use designs and tools that can make "green" technological resources more effective. Examples are duplex printing (c3) and paper reuse ( $\left(c_{1}, c_{2}\right)$, as well as actions such as setting equipment to hibernate during long idle periods and switching computers off when leaving the office (c3). These show technological consequences aligned to "green" thinking. As to the technological conditions, it is worth mentioning that flexible technological innovations (i.e., those allowing users greater control of their interaction with the technology and its characteristics) are the most critical ones, therefore requiring more effort from the mediation team. Certain practices, such as replacing printed reports by digitalized documents (c1, c2, c3), eco-font use (c1), and paper reuse $\left(c 1, c_{2}\right)$ will only work if users commit to them in their routine. The use of, or replacement for, more efficient machines ( $\left.c_{1}, c_{2}, c_{3}\right)$, server virtualization (c1, c2, c3), thin clients (c2), and (even) printing monitoring (c1, c2, c3), which have all been classified as strict technological innovations, are situations whose dependence on, or acceptance by users is low or irrelevant to their use/institutionalization.

Orlikowski (1992) calls interpretive flexibility the degree to which users of a technology are engaged in its constitution (physically and/or socially), whether during its development or use. Interpretive flexibility is an attribute of the relationship between humans and technology and hence it is influenced by characteristics of the material artifact (e.g., the specific hardware and software), characteristics of the human agents (e.g., experience, motivation), and characteristics of the context (e.g., social relation, task assignment). However, she recognizes that the interpretive flexibility of any given technology is not infinite. On the one hand, it is constrained by the material characteristics of that technology. Technology is at some level physical in nature and hence bounded by the state of the art in material, energy, and so on. On the other hand, it is constrained by the institutional context (structures of signification, legitimation, and domination) and different levels of knowledge and power affecting actors as the technology is designed and used (Orlikowski, 1992, p. 409).

Another important aspect in this process is that using these initiatives on an ongoing basis causes users to give their feedback to the mediation team (IT managers) as to the results achieved through Green IT. In other words, benefits and potential improvements of process/technology are revealed (arrow 10b). Printing monitoring (c3), which not only decreased the consumption of non-renewable inputs and pollutants but also reduced expenses, and the introduction of thin clients (c2), which lowered energy consumption, maintenance, downtime, and costs (since the equipment is pre-configured and users themselves can solve most incidents), can be cited as good examples of processes and "green" technologies that result in improvements for both organizations and the environment.

It is worth pointing out that, in order to get this feedback, Green IT must be functioning and users must have conditions to use it. This enables users to compare different available resources ("green" and traditional technologies) while providing information to the IT team so that improvements can be made in the structuration process of a technology. However, the feedback relationship is also conditioned by mediation activities. The cases studied revealed difficulties concerning changing behavior and habits (c1, c2 and c3), using certain technologies (c3), and the awareness that these practices bring environmental and organizational benefits $\left(c_{1}, c_{3}\right)$. However, certain technological conditions are so strict that there is neither feedback nor mediation adjustments involved. In these cases, users merely use the technology without any possibility or need to question it.

\section{Greater environmental sustainability orientation as a consequence of Green IT use}

When users apply Green IT continuously, they legitimate different patterns, configurations, and policies; as a consequence, they reinforce some organizational principles (arrow 4). The interviewees reported such influences when mentioning the benefits from the adoption of "green" practices, even though economic advantages were mentioned most often. They cited reduction in energy, paper, and toner cartridge consumption (c1, c2, c3), decrease in telephone costs (c1), less maintenance (c2) and equipment purchase expenses (c2), in addition to increase in machine life cycles (c1, c2). They also reported the following perceptions as environmental benefits: environmental awareness encouragement (c1) and more physical space (c2). In the context of the companies investigated, examples of recurrent Green IT practices were: printing monitoring $\left(c_{1}, c_{2}, c_{3}\right)$, document digitalization $\left(c_{1}, c_{2}, c_{3}\right)$, recycled paper use $\left(c_{1}, c_{2}, c_{3}\right)$, paper reuse $\left(c_{1}, c_{2}\right)$, duplex printing $\left(c_{1}, c_{2}, c_{3}\right)$ and replacing old 
equipment with more power-efficient ones (c2, c3). Our analysis of the cases shows that environmental sustainability outcomes are due to practices usually introduced in the organization as a means to economic benefits. Thus, the environmental dimension arises as a positive consequence of changes promoted for economic aspects.

Reinforcing the institutionalization of environmental sustainability as a property of the organization enables people to carry out different "green" practices not only in the IT area but also in other departments (arrow 1). When a change occurs in institutional properties, such as becoming environmentally aware of resource shortage and that it is necessary to recycle technological equipment and discharge it properly (c1, c2), this means that Green IT has contributed to institutionalize the organization's concern for different environmental issues. This situation leads to a change in work methods that can favor environmental sustainability initiatives. In this context, Green IT influences the behavior and actions of IT users and managers, since the phenomenon was collectively accepted and generated changes in the institutional properties. Evidence of these changes is the behavior and habits of several groups of IT users who now switch off equipment when leaving the office, ask for more powerefficient equipment (i.e., Energy Star or LEED-certified), separate organic garbage from recyclable waste, and monitor toxic residues even after handing them to recycling companies that collect equipment and parts such as batteries, bulbs, and ink cartridges.

By analyzing the cases, we were able to see that: (1) the adoption of Green IT practices is triggered by the IT area when it first identifies new "green" technologies that will be implemented by the organization; thus, we can see the need to associate technical and computational knowledge with issues related to eco-efficiency and eco-equity; (2) Green IT's structuration process and its interrelation with the property of sustainability are mutually constructed by users and the IT team, rather than autocratically imposed; (3) the mediation in the metastructuration process is key to introducing open, complex technologies, as this mediation allows the technology assimilation process, encourages users to adopt it, and makes it a technology-in-use; (4) the model helps understanding the dynamics of the Green IT phenomenon and how it develops within organizations, thus institutionalizing environmental sustainability in multiple levels; (5) Green IT practices in organizations can also be studied by analyzing rules and resources through Giddens' (1984) three modality types: facilities (e.g., hardware and software such as electronic invoicing, server consolidation, and corporate messenger applications), norms (e.g., print quotas, computer hibernation mode for long idle periods, switching computers off when leaving work), and interpretive schemes (e.g., reducing energy, paper, and toner cartridge consumption brings both environmental and organizational benefits); (6) using Green IT can provide better conditions (structures enacted in the use of technology) to trigger new "green" practices (not necessarily IT-related); and that (7) the institutional properties related to economic and legal aspects still guide most Green IT initiatives in organizations (institutional conditions, according to Orlikowski, 2000); however, they have prompted greater concern for the environment and the future of society.

As to managerial implications, this study can help organizations that wish to engage - or deepen engagement in the movement for environmental sustainability through Green IT practices. In this sense, the study suggests that Green IT has an important role in transforming technological and interpretive conditions, thus helping to change the status quo of the organization. With regard to transforming technological conditions, we found that technology per se is necessary but not sufficient to structure the environmental sustainability property. This change occurs when a particular technology is chosen and properly used for that purpose. For example, many companies are currently purchasing computer printers and multifunction printers that can automatically print on both sides of paper sheets, yet failing to use it in every activity in the company. The same occurs with eco-fonts, hibernate function, and the digitization of documents, among others. Therefore, although the organization has the proper technology to enable this change, it is not occurring. Consequently, the IT team should - after searching and choosing new, "green" technologies - test, disseminate, and guide best Green IT practices in the organization, as well as develop and adapt information systems and business processes that exploit technological resources for the sake of environmental sustainability. Additionally, it is worth stressing the importance of top management support, through establishing certain organizational policies, norms, and guidelines that legitimize the IT team's actions, thus favoring Green IT metastructuration and structuration processes.

As to transformations in interpretive conditions, the study suggests that it occurs through technology-in-use. As they use Green IT artifacts, users develop meanings and emotional attachments related to environmental sustainability that reinforce their use as Green IT practices, bringing both environmental and organizational benefits by reducing energy, paper, and toner cartridge consumption, maintenance and purchase expenses, while increasing computer life cycles. Accordingly, the role of the IT team is key to develop performance indicators, by using measurement and consumer control tools and by disseminating the results achieved. This allows showing users the positive effects of these Green IT initiatives on environmental issues. 


\section{FINAL REMARKS}

The purpose of the present study was to explain the dynamics of Green IT metastructuration and structuration processes in organizations in order to allow a perception of the development of environmental sustainability as an institutional property of organizations. Therefore, by achieving its purpose, this study contributes to understanding how the structuration process of Green IT practices occurs in organizations, in light of the model proposed by Orlikowski et al. (1995). The study also provides empirical experiences, i.e., three case studies, and continues the discussion on the characteristics of organizations that adopt those practices. Green IT is an organizational phenomenon that has grown under different kinds of pressure of the society towards reducing the environmental risks generated by organizations.

The theoretical framework adopted in our analysis emphasized IT teams' role in institutionalizing the environmental dimension of sustainability in organizations, since the adoption process of these various practices applied to the technological area has been mainly triggered and fostered by IT personnel. This study also allowed greater understanding of the interrelation among technology, people, and organizations' institutional properties. Moreover, it shows how this interaction affects and is affected by people's behaviors, attitudes, and cognition, as well as by the organization itself, thus changing the context within the company. In addition, the adoption of more flexible "green" technologies depends on users' acceptance in order to become institutionalized. Therefore, these technologies need more metastructuration than rigid practices where users have little or no say on using them or not. In the context of this study, the structurational model of technology was adequate to investigate the Green IT phenomenon. Just as certain organization structural properties can influence human agents towards adopting Green IT, so too can its use reinforce the environmental dimension of sustainability as an institutional property of the organization.

Some limitations of this study are due to the fact that we analyzed data for a single time point; a longitudinal analysis could have shown new, different connections. It is also relevant to conduct other studies to show the adoption of different Green IT initiatives and their impacts. A number of Green IT practices are most likely being carried out in organizations that were not mentioned in the cases analyzed here. Correlated studies and new research should be conducted to investigate different companies, activities, and contexts. Finally, we hope this study can help managers understand how Green IT's metastructuration and structuration processes occurs in organizations, thus contributing to implement these technologies in their organizations. This research also aims to help researchers interested in developing studies on models of Green IT adoption and consequences. Therefore, future studies should approach IT institutionalization in all social contexts and include models to measure different variables and their associations with the subject.

\section{REFERENCES}

Barata, J., Quelhas, O., Costa, H., Gutierrez, R., Lameira, V. de J., \& Meiriño, M. (2014). Multi-criteria indicator for sustainability rating in suppliers of the oil and gas industries in Brazil. Sustainability, 6(3), 1107-1128. doi:10.3390/su6031107

Bose, R., \& Xin, R. (2012). Green IT adoption: A process management approach. International Journal of Accounting and Information Management, 2o(1), 63-77. doi:10.1108/18347641211201081

Brooks, S., Wang, X., \& Sarker, S. (2010). Unpacking green IT: A review of the existing literature. Proceedings of the Americas Conference on Information Systems 2010, Lima, Peru.

Claro, P., Claro D., \& Amâncio, R. (2008). Entendendo o conceito de sustentabilidade nas organizações. RAUSP-Revista de Administração da Universidade de São Paulo, 43(4), 289-300.

Dao, V., Langella, I., \& Carbo, J. (2011). From green to sustainability: Information technology and an integrated sustainability framework. Journal of Strategic Information Systems, 20(1), 63-79. doi:10.1016/j. jsis.2011.01.002

Dedrick, J. (2010). Green IS: Concepts and issues for information systems research. Communications of the Association for Information Systems, 27(1), 11-18.

Elkington, J. (2001). A teoria dos três pilares. São Paulo: Makron Books.

Elliot, S. (2007). Environmentally sustainable ICT: A critical topic for IS research? [Paper 115]. Proceedings of Pacific Asia Conference on Information Systems 2007, Auckland, Australia.

Feldman, M., \& Orlikowski, W. (2011). Theorizing practice and practicing theory. Organization Science, 22(5), 1240-1253. doi:10.1287/ orsc. 1100.0612

Giangreco, A. (2002). Conceptualisation and operationalisation of resistance to change. Liuc Papers, (103), 1-28.

Giddens, A. (1984). The constitution of society. Berkeley, CA: University of California Press.

Jenkin, T., Webster, J., \& McShane, L. (2011). An agenda for 'green' information technology and systems research. Information and Organization, 21(1), 17-40.

Jones, M., \& Karsten, H. (2008). Giddens's structuration theory and information systems research. MIS Quarterly, 32(1), 127-157.

Ko, M., Clark, J., \& Ko, D. (2011). Investigating the impact of "green" information technology innovators on firm performance. Journal of Information Technology Management, 22(2), 1-12.

Lunardi, G., Alves, A., \& Salles, A. (2012). TI verde e seu impacto na sustentabilidade ambiental. Anais do Encontro Nacional da Associação Nacional dos Programas de Pós-Graduação em Administração, Rio de Janeiro, 36.

Lunardi, G., Frio, R., \& Brum, M. (2011). Tecnologia da informação e sustentabilidade: Levantamento das principais práticas verdes aplicadas à área de tecnologia. Gerais: Revista Interinstitucional de Psicologia, 4, 159-172. 
Melville, N. (2010). Information Systems innovation for environmental sustainability. MIS Quarterly, 34(1), 1-21.

Molla, A., \& Abareshi, A. (2012). Organizational green motivations for information technology: Empirical study. Journal of Computer Information Systems, 52(3), 92-102.

Molla, A., Cooper, V., Corbitt, B., Deng, H., Peszynski, K., Pittayachawan, S., \& Teoh, S. (2008). E-readiness to greadiness: Developing a green information technology readiness framework. Proceedings of the $19^{\text {th }}$ Australasian Conference on Information Systems, Christchurch, New Zealand.

Murugesan, S. (2008). Harnessing. Green IT: Principles and practices. IT Professional, 10(1), 24-33. doi:10.1109/mitp.2008.10

Orlikowski, W. (1992). The duality of technology: Rethinking the concept of technology in organizations. Organization Science, 3(3), 398-427. doi:10.1287/orsc.3.3.398

Orlikowski, W. (2000). Using technology and constituting structures: A practice lens for studying technology in organizations. Organization Science, 11(4), 404-428. doi:10.1287/orsc.11.4.404.14600

Orlikowski, W., \& Gash, D. (1994). Technological frames: Making sense of information technology in organizations. ACM Transactions on Information Systems (TOIS), 12(2), 174-207. doi:10.1145/196734.196745

Orlikowski, W., \& Robey, D. (1991). Information technology and the structuring of organizations. Information Systems Research, 2(2), 143-169. doi:10.1287/isre.2.2.143

Orlikowski, W., Yates, J., Okamura, K., \& Fujimoto, M. (1995). Shaping electronic communication: The metastructuring of technology in the context of use. Organization Science, 6(4), 423-444. doi:10.1287/ orsc.6.4.423

Ozturk, A., Umit, K., Medeni, I. T., Ucuncu, B., Caylan, M., Akba, F., \& Medeni, T. D. (2011). Green ICT (information and communication technologies): A review of academic and practitioner perspectives. eBusiness and eGovernment Studies, 3(1), 1-16.

Pozzebon, M., Diniz, E. H., \& Jayo, M. (2009). Adapting the structurationist view of technology for studies at the community/societal levels. In Y. K. Dwivedi (Ed.), Handbook of research on contemporary theoretical models in information systems. New York: IGI Publishing.

Salles, A., Alves, A., Dolci, D., \& Lunardi, G. (2013). Adoção de práticas de TI verde nas organizações: Um estudo baseado em mini casos. Anais do Encontro de Administração da Informação, Bento Gonçalves, Brasil, 4.

Schmidt, N., Erek, K., Kolbe, L., \& Zarnekow, R. (2010). Predictors of green IT adoption: Implications from an empirical investigation. Proceedings of Americas Conference on Information Systems 2010, Lima, Peru.

Slaper, M., \& Hall, T. (2011, Spring). The triple bottom line: What is it and how does it work? Indiana Business Review. Retrieved from http:// www.ibrc.indiana.edu/ibr/

Sisaye, S., \& Birnberg, J. (2010). Extent and scope of diffusion and adoption of process innovations in management accounting systems. International Journal of Accounting \& Information Management, 18(2), 118-39. doi:10.1108/18347641011048110

Watson, R., Boudreau, M., \& Chen, A. (2010). Information systems and environmentally sustainable development: Energy informatics and new directions for the IS community. MIS Quarterly, 34(1), 23-38.

World Commission on Environment and Development. (1987). Our common future. London: Oxford University Press.

Yin, R. (2001). Estudo de caso: Planejamento e métodos (2. ed.). Porto Alegre: Bookman.

Zhang, J., \& Liang, X. (2012). Promoting green ICT in China: A framework based on innovation system approaches. Telecommunications Policy, 36(10-11), 997-1013. doi:10.1016/j.telpol.2012.09.001 